\title{
Saída do segundo armário: análise das narrativas autobiográficas de Felipe Mastrandéa
}

\section{Robson Evangelista dos Santos Filho}

Mestrando; Universidade Federal de Viçosa, Viçosa, MG, Brasil robsonevangelistasantosfilho@gmail.com

\section{Mariana Ramalho Procópio Xavier}

Doutora; Universidade Federal de Viçosa, Viçosa, MG, Brasil mariana.procopio@ufv.br

\begin{abstract}
Resumo
No presente artigo, apresentamos uma discussão sobre visibilização de temáticas da esfera do privado (SENNETT, 1988) e do segredo (SEDGWICK, 1990), por meio da análise de narrativas autobiográficas de Felipe Mastrandéa em seu canal no YouTube, em que o vlogger revela ser soropositivo. A partir dessa análise, objetivamos perceber como se dá a construção dessas videografias de si (COSTA, 2007; 2009), assim como a saída do chamado segundo armário (MISKOLCl, 2012a). Para tanto, recorremos a bibliografias sobre diários contemporâneos na internet e sobre o HIV e, uma vez que esse vírus, assim como outras questões relacionadas ao sexo, é alocado no âmbito do sigilo, principalmente em razão do estigma a ele atribuído historicamente, abordamos temas como público versus privado, exposição de intimidade e regimes de visibilidade, valendo-se das contribuições de Arfuch (2010), Bruno (2013), Sibilia (2003; 2016), Goulemot (2009), Ranum (2009), Foisil (2009), dentre outros autores. Como principais resultados, percebemos que as videografias são marcadas por um imbricamento do público e do privado. Neste caso específico, o domínio pessoal é publicizado com função estratégica, para adquirir visibilidade e manter um status de webcelebridade. No entanto, essa revelação é parcial, uma vez que Felipe Mastrandéa confere mais importância à exposição da identidade homossexual e menos à soropositividade. Além disso, contar que convive com HIV poderia ser utilizado por ele como um posicionamento contra discursos preconceituosos e discriminatórios, entretanto, o vlogger acaba, na contramão, reforçando os estereótipos relativos à promiscuidade e à irresponsabilidade.
\end{abstract}

\section{Palavras-chave}

Videografias. YouTube. Felipe Mastrandéa. Armário. HIV. 


\section{Introdução}

Na contemporaneidade, a vida pode ser contada de diversas formas e por variados gêneros. As inúmeras possibilidades de registros do eu integram o que Leonor Arfuch (2010) denominou de espaço biográfico. Essa proposição ultrapassa as narrativas biográficas canônicas, abrangendo a multiplicidade de modalidades mais recentes, incluindo as novas narrativas midiáticas. As autobiografias, por exemplo, deixaram de ser consideradas um gênero exclusivamente literário e tornaram-se presentes também em outros espaços, dando origem a outros modos de os indivíduos narrarem a si mesmos.

Como uma dessas práticas autobiográficas contemporâneas, pode-se citar as videografias de si encontradas no YouTube. Bruno Costa (2009) as define como registros autobiográficos em vídeo que caracterizam-se por relatos confessionais com desejo pela exposição do eu. Popularmente conhecidas como vlogs, junção de vídeos e blogs, representam a evolução dos antigos diários pessoais de formato textual, consistindo em diários em vídeo, sem edições complexas ou muita produção, em que os indivíduos narram informalmente perante a câmera os acontecimentos do seu dia (DORNELLES, 2014). Apesar de se valerem de um novo formato, mantêm o caráter autobiográfico e o registro das particularidades dos seus produtores, os vloggers, mas agora divulgadas e disponíveis para todos. É na internet que essas narrativas encontram um espaço propício, principalmente com as possibilidades oferecidas pela $W e b 2.0$, segunda geração da internet, marcada pela participação ativa dos usuários na produção e compartilhamento de conteúdos no ciberespaço, o que lhes conferiu autonomia na criação de visibilidade, sem que precisassem depender de terceiros. Graças a essas potencialidades, podem se narrar para um número incalculável de pessoas (BRUNO, 2013).

As produções de Felipe Mastrandéa ${ }^{1}$ no YouTube são exemplos dessas videografias de si. Em seu canal Fmastrandea ${ }^{2}$ (MASTRANDÉA, 2017), criado em junho de 2014 e atualmente com 330 vídeos, 531 mil inscritos e mais de 104 milhões de visualizações ${ }^{3}$, o vlogger apresenta peculiaridades da sua vida sexual. Em agosto de 2017, ele usou a plataforma para revelar ser soropositivo. Nota-se, nesse caso, em que Felipe Mastrandéa já era assumidamente gay, o que Richard Miskolci (2012a) chamou de segundo armário, referindo-se ao novo regime de visibilidade que emergiu para os homossexuais com o surgimento da epidemia do HIV na década de 1980. Eve Sedgwick (1990) aponta que o

\footnotetext{
1 Felipe Mastrandéa possui 27 anos, mora em Itapetininga - SP, é formado em Letras e trabalha atualmente como professor de inglês. Criou o canal Fmastrandea para, segundo ele, compartilhar suas experiências enquanto gay.

Disponível em www.youtube.com/user/fmastrandeacanal.

3 Dados disponíveis em 20 de maio de 2018.
} 
armário, uma metáfora de privacidade que faz referência a pares como público/privado e segredo/revelação, jamais deixa de estar presente para os homossexuais e, ainda, que novos armários vão se impondo com demandas de sigilo ou exposição conforme a situação, como é o caso do HIV. Assumir ser soropositivo seria, pois, deixar este armário e confrontar a imagem de intimidade que ele oferece.

Para Arfuch (2010), é no processo de se narrar que são selecionadas as vivências que se destacam do fluxo efêmero da vida e que merecem, então, ser contadas. Geralmente, são privilegiadas as informações de carga positiva, porém, no caso em questão, há a exposição de algo historicamente demarcado e estigmatizado como negativo. Isso leva à reflexão sobre as motivações de Felipe Mastrandéa ao revelar um segredo supostamente inconfessável, se seus testemunhos em primeira pessoa estão ancorados na intenção de autoconhecimento, autoajuda, ajuda a outrem, superação, interesse narcísico em obter likes, seguidores e repercussão ou por outros propósitos.

Nessa perspectiva, o presente artigo objetiva, então, analisar como se dá a construção discursiva da narrativa autobiográfica por Felipe Mastrandéa em alguns dos vídeos do seu canal. A análise debruça-se principalmente sobre o vídeo Sou soropositivo recém-nomeado como Para maiores de 18 anos (289) - no qual o vlogger revela conviver com HIV, mas também sobre excertos de vídeos posteriores - Para maiores de 18 anos (291) ${ }^{5}$ e Para maiores de 18 anos (292) ${ }^{6}$ - nos quais Felipe Mastrandéa dá continuidade à discussão, respectivamente narrando como descobriu que estava infectado e discorrendo a respeito da repercussão e dos comentários dos internautas após o primeiro vídeo.

Essa análise, no entanto, não pretende fazer uma generalização do canal, mas sim concentrar-se especificamente nestes vídeos que abordam a questão da soropositividade para observar como ocorre a revelação, assim como quais os limites entre público e privado nos relatos pessoais de Felipe Mastrandéa. Dessa forma, a análise consiste em um estudo de caso que levará em consideração tanto os componentes estruturais quanto o conteúdo dos objetos em questão e será subsidiada por arcabouços teóricos que fazem um resgate histórico sobre o HIV e sobre as autobiografias, valendo-se também de referenciais a respeito da exposição da intimidade e dos regimes de visibilidade.

\footnotetext{
4 Disponível em: www.youtube.com/watch?v=Q4AunbY9YXQ.

5 Disponível em: www.youtube.com/watch?v=qzBNg3amdGk\&t=19s.

6 Disponível em: www.youtube.com/watch?v=LEQ9-jol7Fs\&t=74s.
} 


\section{Dos diários pessoais às videografias no YouTube}

Diários pessoais são gêneros autobiográficos nos quais tradicionalmente se registram o cotidiano e o íntimo. De acordo com Fernanda Bruno (2013), difundiram-se no século XIX como prática de narrativa do eu e dos segredos inconfessáveis, privilegiando temas como sexualidade, amor, corpo e saúde, relatados de formas diversas, mas com o objetivo comum de decifrar a si mesmo. Esses escritos, segundo Paula Sibilia (2003), surgem no contexto de delimitação dos espaços público e privado.

Para Richard Sennett (1988), a demarcação destes âmbitos e, por conseguinte, a valorização da privacidade, está relacionada ao declínio da vida pública na modernidade, com a formação de uma nova cultura urbana, secular e capitalista. Da mesma forma, também está relacionada ao crescimento das cidades e da violência em seus centros, que, pelo medo e perigo gerados, fazem que o espaço público torne-se apenas de passagem e não mais de permanência. Assim, os indivíduos passam a buscar um território mais íntimo tanto para refúgio, defesa e preservação quanto para acolher as suas vidas interiores que estavam emergindo e construir, dessa forma, as suas identidades.

Ao projetar uma retrospectiva histórica da delimitação entre público e privado, pode-se considerar que a intimidade não existia na Idade Média, constituída por uma sociedade comunitária que excluía práticas particulares. Em contrapartida, com a Renascença, se dá a instauração do espaço íntimo para os indivíduos se distanciarem dos olhos da comunidade e do poder. Assim, nesta época, coexistem os dois espaços, público e privado: às atividades sociais urbanas somam-se as habitações, que em oposição às praças e logradouros, vão tornando-se lugares privados (GOULEMOT, 2009) nos quais era possível ser si mesmo, ficar à vontade e se expressar, principalmente pela escrita, em especial de diários, tida como uma atividade íntima. Outros locais também eram considerados propícios à busca de si, como os jardins, os quartos e as alcovas, além dos gabinetes dos palácios renascentistas, mobiliados com mesa, cadeira, estantes e livros e destinados a leituras, orações, contabilidades e conversas confidenciais, e dos escritórios, que poderiam tanto ser um cômodo quanto um móvel (RANUM, 2009). Todos estes ambientes eram convidativos à introspecção, muitas vezes passada para o papel, em um período marcado pelo furor de escrever para autoconhecimento e firmação do eu.

De acordo com Goulemot (2009), a partir do século XVI, as escritas de memórias tornaram-se habituais pelos representantes mais eminentes da elite social, estando, dessa forma, restritas a pessoas que participavam da história pública como atores ou testemunhas privilegiadas dos fatos e detendo-se onde começava o íntimo. 0 privado era excluído como se 
não existisse, não interessasse ou fosse impróprio: o dizível se restringia ao espaço público. Conforme complementa Foisil (2009), os livros de memórias dessas personalidades públicas, destinados à leitura, relatavam a vida pública, mas pouca ou nenhuma vida privada, narrando apenas o que todos podiam ver. Eram mais retratos do que autobiografias e, por isso, não devem ser confundidas, uma vez que os relatos autobiográficos, que surgiram mais tarde, eram retrospectivos e evidenciavam individualidade.

Essa ênfase no indivíduo é intensificada com os diários, que pretendiam engrandecer os autores e suas visões particulares sobre o coletivo, com depoimentos apresentados como verdade sem a necessidade de que fossem comprovados. Todavia, ao contrário das memórias, os diários não eram elaborados com vistas à publicação, o que só acontecia posterior e/ou acidentalmente. Estas produções, como diários urbanos, de viagem e de contas, que cresceram na era clássica, ainda não podem ser consideradas, no entanto, como diários íntimos, que trazem confidências e fazem do sujeito que escreve o seu objeto (GOULEMOT, 2009).

Nessa perspectiva, enquanto a literatura medieval, marcada por narrativas orais, canções e obras teatrais, ignorava o espaço privado, a intimidade e o particular com estes atos não individuais, anônimos e de temáticas referentes ao coletivo, a literatura da era clássica trouxe diários íntimos, memórias e romances em primeira pessoa, relatos que vão se constituindo como gêneros ou categorias (GOULEMOT, 2009) essenciais da escritura privada no final do século XVII e durante o século XVIII (FOISIL, 2009). Assim como cartas, retratos e autorretratos, consistem em objetos-relíquias que, associados ao íntimo do ser e carregados de emoções e afetos humanos, serviam como registros da existência para serem guardados como lembranças (RANUM, 2009).

Segundo Arfuch (2010), as confissões de Jean-Jacques Rousseau no século XVIII, caracterizadas por uma narração exacerbada da intimidade, revelação sem pudor dos segredos pessoais, voz autorreferencial, análises de si mesmo e percepção de um destinatário, marcam a origem das biografias e a travessia definitiva do limiar entre o público e o privado. Se as confissões estavam relacionadas à insignificância diante de algo maior, por meio de registros principalmente religiosos, com o retorno no olhar para o homem, estas confissões passam a ser um modo de autoconhecimento, atividade exercida a partir da descoberta da solidão, uma vez que até o final do século XVII ninguém ficava a sós. Assim, o individualismo se consolida, a escrita autógrafa surge, com a afirmação da vida interior por meio de relatos pessoais em substituição aos anteriores relatos da comunidade, e a barreira entre público e privado deixa de existir. 
Desde então, os relatos de si tornaram-se recorrentes, mas, segundo Sibilia (2003), tiveram fim nas últimas décadas do século XX. Na época, porém, ninguém imaginava que os diários logo retornariam como novas modalidades em ambientes virtuais, aproveitando as possibilidades oferecidas pela tecnologia e fazendo ressurgir as autobiografias clássicas, adaptadas ao contexto contemporâneo. Como afirma Richard Miskolci (2012a, p. 32), "O uso contemporâneo das mídias digitais é o capítulo mais recente de uma longa história de [...] borramento das fronteiras entre o privado e o público [...]", uma consequência da popularização do telefone e do desenvolvimento dos computadores pessoais na década de 1980, o que, combinado, culminou na expansão da internet a partir do final da década de 1990 e convergiu, no século XXI, para o uso de aparelhos portáteis.

Bruno (2013) aponta que a exposição da intimidade tornou-se recorrente com a popularização do uso de webcams em 1996 e de narrativas de si em blogs, fotologs e videologs na Internet a partir de, respectivamente, 1999, 2002 e 2005. Para ela, é consenso que detalhes da vida privada jamais foram tão visíveis e publicizados como recentemente, pois, se antes a intimidade era preservada, o lugar do segredo e da resistência ao coletivo, na contemporaneidade isso se inverte e a intimidade se volta para fora a fim de se mostrar ao outro, convidando-o a penetrar no íntimo e corriqueiro, principalmente nestes ambientes comunicacionais tecnológicos, um campo fértil dos dispositivos de visibilidade, tais como as redes sociais. Inaugura-se, assim, um novo regime de visibilidade, envolvendo outras práticas do ver e ser visto.

Conforme aponta Sibilia $(2003 ; 2016)$, esse interesse pelas pessoas comuns e pelos seus cotidianos, a chamada virada subjetiva, tem aumentado muito nos últimos anos, tornando os depoimentos pessoais cada vez mais valorizados. Isso, principalmente, porque essas pequenas narrativas vivenciais marcam a decadência dos grandes relatos e das figuras ilustres e exemplares das biografias canônicas. A propagação da dimensão biográfica traz, então, aqueles que compareciam nas histórias apenas como grupo e não como indivíduos (COSTA, 2009), pois as próprias autobiografias, até algumas décadas atrás, eram um privilégio dos membros da classe dominante (LEJEUNE, $1994^{7}$ apud COSTA, 2009).

Da mesma forma, os relatos íntimos e confessionais também têm se intensificado, presentes em gêneros autobiográficos diversos, como na escrita, nas artes plásticas, no cinema, no teatro, no audiovisual (ARFUCH, 2010). Ao discorrer sobre a autobiografia audiovisual, Júlio Bezerra (2007) apresenta a hipótese de que depois da narração e do romance, a produção autobiográfica em vídeo, assumindo a herança literária das narrativas de si, seria a que "[...] melhor traduz o modo de ser subjetivo do sujeito [...] contemporâneo

LEJEUNE, Philippe. El pacto autobiográfico y otros estudios. Madri: Megazul-Endymion, 1994. Apud Costa (2009). 
[...] [que] desgarrado de uma tradição que fala por ele e produz algum sentido para a sua vida, se vê compelido a falar/escrever/narrar e, agora, a filmar." (BEZERRA, 2007, p. 200).

Como sugere Bruno Costa (2009), a difusão dos aparatos tecnológicos de gravação e reprodução, aliada à consolidação da internet como meio alternativo de geração e distribuição de conteúdo, representa, além da expansão técnica, o surgimento de novas formas de narrativa, como as videografias. 0 autor complementa que a migração de produção audiovisual por profissionais para amadores foi se intensificando e, com isso, cada vez mais pessoas passaram a fazer suas pequenas narrativas em vídeos domésticos e a hospedar em sites como o YouTube. À medida que foram se popularizando e se disseminando, esses vídeos abandonaram o confinamento dos lares para se integrarem à rede mundial, emergindo, assim, milhares de videografias de si cujo traço fundamental parece ser o desejo de registro do self, agora possível a muitos.

Apesar de preservarem especificidades como intimidade, ordinariedade e confissão, embora com adaptações aos formatos contemporâneos, as videografias ou vlogs se divergem em vários aspectos de seus ancestrais pré-digitais, os diários tradicionais. Ambos podem ser práticas solitárias, mas as versões cibernéticas se dão num ambiente de publicidade total para acesso potencial de milhões de pessoas do mundo inteiro, ao passo que escritores dos séculos XIX e XX precisavam se resguardar na privacidade para se autoconstruir e, provavelmente, jamais almejariam projeção tampouco a divulgação de seus segredos, o que, para muitos, inclusive, seria um pesadelo (SIBILIA, 2016). Já para as videografias, a exibição é essencial, uma vez que o espectador é tão importante quanto o autor para que o processo de constituição de sentido se complete (COSTA, 2009).

Além disso, a velocidade das publicações, em tempo real, diminuíram o hiato espacial e temporal com os leitores e espectadores, que outrora talvez só tivessem acesso aos relatos pessoais após a morte dos produtores biográficos. E, ainda, a interação com os receptores consiste em um componente importante (SIBILIA, 2016), pois, enquanto os antigos diários eram discretos e mudos, os atuais confessionários eletrônicos permitem a manifestação de reação, comentários, diálogos, o que pode, mediante a preocupação com o olhar do outro, implicar a produção artificial do eu (HÉNAFF, 2016).

Por todos os motivos mencionados, Paula Sibilia (2016), ao concluir a comparação entre os diários íntimos clássicos e os contemporâneos diários da internet, afirma que se altera a condição, passando por um upgrade, ou seja, a prática continua, mas o sentido muda, consolidando maneiras inéditas de autotematizar e constituir o eu. 


\section{HIV e a configuração de um novo armário}

O HIV é a sigla em inglês para o Vírus da Imonudeficiência Humana, que ataca o sistema imunológico, responsável por defender o organismo de doenças. A transmissão acontece por meio de relações sexuais desprotegidas, compartilhamento de instrumentos perfurocortantes não esterilizados, transfusão de sangue contaminado e de mãe para filho durante a gravidez, no parto ou na amamentação. É importante ressaltar que ter HIV não é o mesmo que ter AIDS, que seria a Síndrome da Imunodeficiência Adquirida, uma fase avançada em que a pessoa infectada atinge baixos níveis das células de defesa, ou seja, o primeiro consiste em um vírus e apenas o segundo pode ser classificado como doença.

De acordo com o relatório do Programa Conjunto das Nações Unidas sobre HIV/AIDS (UNAIDS) $^{8}$, lançado em junho de 2017, estima-se que 36,7 milhões de pessoas vivem com HIV no mundo. No Brasil, em 2016, havia 830 mil pessoas com HIV. Segundo o Ministério da Saúde, $84 \%$ dessas pessoas já foram diagnosticadas, das quais 55\% estão em tratamento. E das que estão tratando, 50\% apresentam carga viral indetectável, ou seja, não transmitem o vírus sexualmente?

O Brasil foi um dos primeiros países, dentre os de renda baixa e média, a fornecer tratamento gratuito para pessoas com HIV, em 1996, pelo Sistema Único de Saúde. Em 2013, adotou algumas estratégias, como oferta de tratamento a todas as pessoas vivendo com HIV, independentemente do estado imunológico, aumento da cobertura de testagem, implantação de campanhas de conscientização, entre outras iniciativas. Em 2015, o UNAIDS reconheceu o país como referência mundial no controle da epidemia. Entretanto, atualmente, ainda conforme o relatório, o Brasil concentra mais da metade de novas infecções de HIV na América Latina e, na contramão do restante do mundo, registrou um aumento de contaminações.

A identificação do HIV em 1981 foi um marco na história da humanidade, com uma ameaça de crise na saúde pública global que tem gerado, deste então, uma exaustiva discussão (BRITO; CASTILHO; SZWARCWALD, 2001). Diante de uma nova infecção, que se disseminava e se agravava rapidamente, repercutiu na coletividade um discurso que, apoiado em valores morais e em ideias de uma enfermidade incurável e mortal relacionada à sexualidade, provocava o medo de contágio e a sensação de risco iminente, ocasionando a marginalização dos grupos que estavam associados ao vírus (ALMEIDA; LABRONCINI, 2007). Na época, a AIDS ficou conhecida como "peste rosa", "câncer gay", "doença dos gays",

\footnotetext{
8 Dados disponíveis nos endereços: unaids.org.br/tag/relatorio-unaids-2017. Acesso em 05 de fevereiro de 2018.

9 Dados disponíveis em www.aids.gov.br/node/65068. Acesso em 05 de fevereiro de 2018.
} 
colocando os homossexuais como irresponsáveis e pervertidos que alastram a doença do século (ALMEIDA, 2016).

Como ressalta Miskolci (2012b), a epidemia de AIDS é um fato biológico, mas também uma construção social, uma vez que poderia ter sido constituída como uma doença viral por surgir a partir de um vírus e, no entanto, foi delimitada como doença sexualmente transmissível, como um castigo aos homossexuais, indivíduos que não seguiam a ordem sexual tradicional. Houve, portanto, uma patologização dessas sexualidades dissidentes.

É nesse contexto que, segundo Miskolci (2012b), consolida-se a Teoria Queer, especificamente na segunda metade da década de 1980, quando o governo dos Estados Unidos se recusa a reconhecer a AIDS como uma emergência de saúde pública, mostrando, assim, que o conservadorismo se volta contra as demandas sociais. Com isso, o movimento gay e lésbico torna-se mais radical que o movimento da década de 1960 e passa a criticar a sua própria luta política. 0 queer, que associa-se a xingamentos como abjeto, esquisito e anormal, surge, então, como uma reação e resistência à questão biopolítica trazida pela AIDS, argumentando que a problemática não reside na homossexualidade, mas no espaço ao qual são relegados os indivíduos tidos como ameaça à ordem social, uma vez que "O 'aidético', identidade do doente de AIDS, encarnava esse fantasma ameaçador contra o qual a coletividade expunha seu código moral." (MISKOLCI, 2012b, p. 24).

O movimento queer questiona que mesmo gays e lésbicas "reconhecidos e tolerados" são transformados em abjetos em outros momentos. Diferencia-se, nesse sentido, do movimento anterior, que reivindicava o respeito à diversidade, a aceitação e a incorporação à sociedade e que defendia a homossexualidade com base em valores hegemônicos. 0 movimento queer foge, então, desse binário hetero-homo e passa a questionar o par normalanormal, criticando os regimes de normalização da sexualidade, aos quais o próprio grupo de gays e lésbicas se submetiam, e demarcando, a partir disso, uma perspectiva da diferença (MISKOLCI, 2012b).

Apesar de alguns avanços, como o advento dos medicamentos antirretrovirais e a criação de recursos econômicos, políticos, psicológicos e sociais para lidar com a AIDS, ainda prevalecem estigmas, preconceitos e discriminações às pessoas que convivem com HIV, fazendo com que escondam sua condição sorológica pelo receio de se expor (ALMEIDA; LABRONCINI, 2007), uma vez que a sociedade compreende o abjeto como obsceno, como aquele que não deveria ser visto, revelando o seu repúdio sobre estes indivíduos estarem no espaço público (MISKOLCI, 2012b).

Nesse sentido, os homossexuais têm aí um agravante, por serem categorizados como um grupo de risco do HIV. Embora qualquer pessoa possa ser infectada pelo vírus, eles são 
identificados como os mais vulneráveis. De acordo com dados do Ministério da Saúde, dos novos casos registrados entre 2007 e 2016 no Brasil, 65\% são homens e 45\% deles fazem sexo com outros homens ${ }^{10}$. Além disso, desde o surgimento da AIDS, sofrem com a culpabilização, como se a infecção pelo vírus fosse um castigo pelas suas práticas sexuais (ALMEIDA; LABRONCINI, 2007). Conforme já citado, para reverter esta situação, na época, alguns grupos de militância decidiram divulgar a imagem do "gay comportado" que se encaixava no molde heterossexual, num processo de normalização, entretanto, ainda assim, o preconceito continuou (ALMEIDA, 2016). Tudo isso fez com que os indivíduos homossexuais se inserissem no chamado segundo armário, mas há quem, por motivações diversas, abandona este armário, como o vlogger Felipe Mastrandéa, cujas narrativas de si serão analisadas a seguir.

\section{Sexo, estereótipos e desinformação nos relatos de Felipe Mastrandéa: exposição do íntimo motivada por visibilidade e celebrização}

Nos vídeos do seu canal no YouTube, Felipe Mastrandéa narra, sem pudor, as suas experiências sexuais. Recentemente, renomeou todos os seus vídeos como Para maiores de 18 anos, numa referência aos assuntos abordados no canal, majoritariamente de cunho sexual. Tal temática é historicamente pertencente à esfera da intimidade, tida como tabu e, de acordo com Goulemot (2009), tornou-se parte importante da produção literária a partir do século XVIII, numa época de transição e constituição de um espaço que não era marcado pelo selo do secreto nem atingido por proibições no discurso. Estas narrativas parecem ter, conforme matérias na internet e comentários na página, propulsionado a visibilidade de Felipe Mastrandéa, uma vez que, segundo Marcondes Filho (1986), o sexo, juntamente com o escândalo e o sangue, forma o trinômio sensacionalista da mídia que objetiva envolver o público a fim de nele causar impacto e obter sua audiência.

Essa exibição da intimidade e da vida banal na internet traz, então, a discussão sobre os limites entre os âmbitos público e privado. Nolwenn Hénaff (2016), ao questionar em que se transforma o íntimo ao mudar de esfera e se difundir pelas mídias, apresenta a noção de extimidade, formulada por Serge Tisseron, que consiste na intimidade exposta, no movimento que impulsiona os indivíduos a exteriorizarem parte de suas vidas pessoais.

Em geral, os vídeos do canal Fmastrandea apresentam as características estéticas e discursivas das videografias, apontadas por Bruno Costa (2007), como imagens precárias, de

\footnotetext{
${ }^{10}$ Dados disponíveis em uma matéria do site saude.abril.com.br/medicina/homens-jovens-ou-homossexuais-ainda-sao-asgrandes-vitimas-do-hiv. Acesso em 10 de fevereiro de 2018.
} 
produção caseira e descuidada, que criam uma atmosfera de verossimilhança para quem assiste. Apesar de conter imagens gravadas em alta qualidade, os vídeos de Felipe Mastrandéa não possuem produções ou edições complexas, apenas alguns cortes bruscos e movimentos de zoom, próprios de vlogs no YouTube, para dar ritmo às falas e destaque a determinados trechos.

Bruno Costa (2009) aponta que, como as videografias de si prescindem de técnicos, o ato de filmar a si mesmo é propício para a confissão. Segundo o autor, fica evidente que, historicamente, o "[...] vídeo está relacionado ao doméstico, um meio que provê um olhar eletrônico e incita um discurso sobre o self, [...] facilitador para uma espécie de autoanálise de si, [...] que traz um novo ator para o processo, o olhar da câmera." (COSTA, 2009, p. 148), para o qual o falar autobiográfico se dirige. Embora nos vídeos de Felipe Mastrandéa nota-se a presença de alguém que opera a câmera, com quem às vezes ele interage, permanece o caráter confessional, ao narrar em detalhes episódios pessoais de cunho sexual que geralmente não seriam confidenciados.

Os vídeos têm como cenário a sala do apartamento de Felipe Mastrandéa e, por vezes, o seu quarto e o banheiro, o que, além de evidenciar o caráter doméstico e cotidiano das produções típicas dos vlogs, também funciona como um convite aos espectadores para penetrar em sua intimidade e agirem como voyeurs, uma vez que a casa é considerada o lugar reservado das relações pessoais, que outrora demarcou a separação entre os espaços público e privado e, segundo Sibilia (2016), onde são produzidas as subjetividades, o desenvolvimento do eu e transcorridas as atividades íntimas. Esses cômodos, de acordo com Runan (2009), são historicamente demarcados como cenários das atividades reservadas, como banho, nudez, erotismo e relações sexuais.

Dentre o conteúdo do canal, foram selecionados para análise neste artigo três vídeos que têm como temática o HIV. No primeiro deles, Para maiores de 18 anos (289), Felipe Mastrandéa revela ser soropositivo. Essa revelação, conforme mencionado, consiste na saída do chamado segundo armário a partir da exposição de uma informação considerada como pertencente ao âmbito privado e cujo sigilo é defendido pela Declaração dos Direitos Fundamentais da Pessoa Portadora do Vírus da AIDS, aprovada em 1989 durante o Encontro Nacional de ONG's/AIDS.

Na declaração de Felipe Mastrandéa, pode-se perceber a referência à confissão, principalmente pelo uso da palavra "assumir", embora tenha sido modificada em seguida, por estar relacionada a imaginários sociais que se relacionam à ideia de culpa, crime e pecado (ALMEIDA, 2016), o que poderia reforçar a ideia de culpabilização e estereótipos 
como o da promiscuidade e irresponsabilidade, recorrentemente atribuídos às pessoas que convivem com HIV.

A revelação é justificada logo na sequência por Felipe Mastrandéa, que diz que decidiu trazer isso a público, mesmo tempo depois, para ajudar outros soropositivos. 0 vlogger conta que atualmente está bem o bastante e que "o canal está grande o suficiente para expor". Essas palavras expressam a importância que se dá à visibilidade ao realizar confissões como essa, que talvez não seriam feitas caso o canal ainda fosse desconhecido, se não possuísse mais de meio milhão de seguidores ou se não tivesse o potencial de repercussão que obtém atualmente na internet, daí ter aguardado para que conseguisse atingir mais pessoas. Por diversas vezes, Felipe Mastrandéa faz referência à autonomia na criação de visibilidade ao comentar, por exemplo, que sente-se "grato, feliz e orgulhoso por ter essa plataforma" e que foi graças a essas possibilidades advindas do seu canal que decidiu se expor.

Essa questão sobre os regimes de visibilidade dialoga com a discussão feita por Bruno (2013), que apresenta as práticas do ver e ser visto ao longo do tempo. De acordo com a autora, há, num primeiro momento, um modelo sinóptico, em que muitos observam poucos, como nos espetáculos da corte na sociedade da soberania. Já num segundo momento, instaura-se o modelo panóptico, em que poucos observam muitos, dirigindo a visibilidade para os indivíduos comuns, para as massas e para os anormais, como o que acontecia em escolas, prisões, fábricas, hospitais e manicômios das sociedades disciplinares. Em seguida, com o advento dos meios de comunicação da sociedade de massa, se dá o retorno para o modelo sinóptico, novamente com foco nas elites, mas a partir da espetacularização das celebridades. E, atualmente, a visibilidade volta-se mais uma vez para os indivíduos comuns, entretanto ancorada em um modelo denominado palinóptico, no qual muitos observam muitos, veem e são vistos de várias formas, como na internet e nos vários dispositivos do ciberespaço, com a exposição deliberada do eu e da vida banal em blogs e redes sociais. Daí a revelação de Felipe Mastrandéa se dar neste universo virtual, no qual, com a transformação do regime de visibilidade, vigora a performatização pública do eu privado (MISKOLCI, 2012a).

Nathalie Heinich (2012) acrescenta a esta discussão ao apontar que a visibilidade passa por uma inversão com a expansão dos sistemas midiáticos. Antes, segundo a autora, a visibilidade era consequência dos méritos e dos grandes feitos, mas a partir do século XX passa a antecedê-lo, sendo um instrumento para adquirir reconhecimento público. Essa lógica se faz presente em vários meios atuais, como no YouTube, onde seus personagens primeiro devem alcançar a visibilidade para depois tornarem-se conhecidos. Felipe 
Mastrandéa, por exemplo, foi tornando-se visível por seus vídeos e acumulando muitos acessos em seu canal até tornar-se conhecido na rede.

No vídeo Para maiores de 18 anos (292), postado uma semana após a revelação do HIV, Felipe Mastrandéa conta que tornou-se notícia em vários sites do Brasil e que as pessoas passaram a comentar sobre, apesar de, segundo ele, "não ser do interesse de ninguém o seu problema de saúde". Essa exploração do fato pela mídia e o interesse das pessoas, exemplificado pelos números significativos de visualizações dos vídeos, podem ser explicados pelo espanto e deleite que, segundo Sedgwick (1990), declarações públicas de saída do armário causam na sociedade. Isso explica o frenesi causado pelas revelações de celebridades em relação à homossexualidade, como, por exemplo, da apresentadora Fernanda Gentil, da cantora Daniela Mercury e do ator Marco Nanini. Da mesma forma, são as revelações em relação à soropositividade, como de Cazuza e Renato Russo, nomes até hoje associados ao HIV, e casos mais recentes, como da artista Conchita Wurst e do humorista Charlie Sheen.

E ser celebridade é um atenuante para reverberar revelações como essas, inclusive considerado por vários autores como critério de noticiabilidade, como para Mario Erbolato (1991), que fala sobre a proeminência ou celebridade dos envolvidos no fato como valornotícia. É o caso de Felipe Mastrandéa, que pode ser definido como subcelebridade ou celetoide, na definição de Chris Rojek (2008), referindo-se àqueles que adquiriram fama repentina na mídia e buscam manter esse status e alcançar a mesma visibilidade das grandes celebridades. Ou, ainda, webcelebridade, que para Graeme Turner (2004), é a persona que cria, gera seu próprio conteúdo e publica as próprias performances de si. Felipe Mastrandéa, já visível no cenário midiático pelo seu canal no YouTube, torna-se pauta, nessa lógica de seleção de notícias, ao expor ser soropositivo, tendo a intimidade e o segredo viralizados, o que provavelmente não aconteceria com a mesma intensidade se fosse um indivíduo anônimo.

Felipe Mastrandéa conta, ainda, que, desde a revelação, as pessoas passaram a acompanhar ainda mais as suas atitudes, uma das consequências da visibilidade atrelada ao que Fernanda Bruno (2013) chamou de vigilância requerida ao apontar que, ao contrário de na modernidade, quando os indivíduos resistiam ao coletivo, na contemporaneidade desejam se expor a ele. A autora complementa que esse regime de vigilância é utilizado como entretenimento nos sites de compartilhamento de imagens e vídeos e nas redes sociais. E, ainda, que gera uma autovigilância (BRUNO, 2013), como pode ser percebido quando Felipe Mastrandéa, também no vídeo 292, faz desabafos sobre os comentários feitos por internautas sobre ele, o "vilanizando e julgando moralmente", o que lhe incomodou. 
Mostra-se, assim, preocupado com a opinião e o retorno desse público. Em alguns momentos do vídeo 289, ele tenta, inclusive, reverter o discurso de culpabilização, como em "acredito que não devo fazer discursinho do tipo 'eu me arrependo', pois não me arrependo de ser HIV positivo" e "não vou fazer a coitada, sou super sexualizado e não vou deixar de ser por conta disso".

Ao justificar a revelação, Felipe Mastrandéa diz "não saio por aí falando que sou HIV positivo como falo que sou gay". A mesma ideia é reforçada quando diz que "não precisa ficar mentindo, mas também não precisa ficar anunciando que é HIV positivo". A partir disso, pode-se perceber uma distinção nas atribuições dadas por ele às saídas do primeiro e do segundo armário, ou seja, às revelações de ser gay e de ser soropositivo. Sair do armário significa "[...] anunciar certa identidade que, a rigor, é considerada menor em determinado contexto sócio-histórico." (ALMEIDA, 2016, p. 242), como a identidade homossexual ou soropositiva. No discurso de Felipe Mastrandéa, não é dada a esta segunda identidade a mesma relevância dada à primeira, como se publicizar ter HIV não fosse tão importante quanto contar que é gay, mantendo, então, esta identidade em segredo.

Almeida (2016) lembra que, do século XX para o XXI, há uma mudança de percepção dos homossexuais, que passam a se identificar como indivíduos homossexuais e assumir esta identidade, deixando, portanto, de se limitarem a pessoas praticantes de atos homossexuais. Com isso, surgem locais e serviços destinados a eles, como os bares e pubs, que possibilitavam encontros e serviam como refúgio, inaugurando o mundo gay ou uma subcultura homossexual, na qual os indivíduos possuíam várias identidades: uma ligada à sua profissão, "mostrada" no cotidiano, e outra "escondida", revelada apenas nestes momentos de lazer. Há aí a demarcação de um armário, quando os indivíduos estabeleciam as situações, os ambientes e os grupos em que admitiam ou não a homossexualidade.

Em seguida, a saída do armário passa a ser compreendida como bandeira de luta, bastante incentivada pelos movimentos como o de libertação e do Orgulho Gay, de modo a dar visibilidade à causa e à comunidade, assim como para reivindicar direitos (ALMEIDA, 2016). Entretanto, conforme aponta Sedgwick (1990), à medida que cresciam as declarações públicas das revelações gays, crescia também o espanto e o deleite, influenciando em estruturas importantes da sociedade. Assim é escasso o número de gays, incluindo os mais afirmativos, que não se mantêm deliberadamente no armário perante figuras importantes do seu círculo de relações pessoais, econômicas ou institucionais (SEDGWICK, 1990). Para a autora, o armário jamais deixa de se afirmar como elemento central para os gays, uma vez que vão se configurando novas demandas de sigilo e de revelação e, assim, novos armários 
temáticos vão surgindo conforme as situações enfrentadas por esses indivíduos, levando-os a ponderar o que expor e o que esconder.

Conforme aponta Richard Miskolci (2012a), ficam mantidas no armário, visando a segurança dos seus indivíduos, todas as identidades anômalas que desviam do que é tido como normal, que não atendem às expectativas coletivas e que são marcadas por formas de reprovação moral e retaliações, principalmente quando inseridas na esfera das relações sexuais e patologias, como é o caso do HIV. Assim, passam a articular uma vida pública, de conhecimento da sociedade, a uma vida privada, mantida no armário. E, mais uma vez, se faz necessário pontuar uma das motivações de Felipe Mastrandéa ao revelar ser soropositivo: a visibilidade que isso vai lhe gerar, o que não adquiriria se mantivesse no armário. Essa necessidade de visibilidade, para Nolwenn Hénaff (2016), parece residir no medo da invisibilidade, como se para existir fosse preciso ser visível.

Nos vídeos analisados, por diversas vezes aparece um discurso de superação, como uma mensagem de inspiração e exemplo direcionada para pessoas que vivem com HIV, como se percebe em "Na época meu mundo acabou, hoje estou bem. Você que está passando por esse problema, essa situação que parece problemática agora, você vai superar, vai ver que não é um bicho de sete-cabeças, vai conseguir se aceitar" e em "Tudo vai ficar bem, a vida segue em frente". O discurso de superação é bastante utilizado na mídia, em diversos formatos, e se relaciona às narrativas clássicas em torno do mito do herói, que, de acordo com Helal (2001), tratam de luta e de enfrentamento de obstáculos aparentemente intransponíveis, levando as pessoas a se identificarem ao evento. Em todas as ocasiões em que comenta que conseguiu superar, Felipe Mastrandéa não traz, porém, a narrativa de como se deu a sua trajetória até este momento de superação, apenas sugere que as pessoas procurem apoio com familiares, amigos e psicólogos.

Felipe Mastrandéa também aproveita para dar orientações sobre a importância de fazer os testes e o tratamento, em caso de diagnóstico positivo para HIV, e para desmitificar as ideias de morte e doença que ainda estão fortemente ligadas ao vírus. Entretanto, ao orientar sobre a necessidade de se cuidar, o vlogger diz que "Você precisa se cuidar, mas também não estou aqui para falar que você deve se cuidar, que deve usar camisinha porque cada um sabe da sua vida", contrariando, assim, os discursos médicos e as campanhas que tentam conscientizar a sociedade sobre a importância da prevenção. Criticado sobre isso, Felipe Mastrandéa se retratou no vídeo 292, afirmando que expôs a sua vida mais honestamente para ajudar outras pessoas e não para incentivar sexo sem camisinha. 


\section{Considerações finais}

Embora Felipe Mastrandéa afirme que não há necessidade em publicizar ser soropositivo, atribuindo diferente importância à saída deste armário em comparação à revelação de ser gay, ele o faz em seu canal com o objetivo de, em suas palavras, ajudar outras pessoas que também convivem com HIV. Para tanto, ele parte da sua narrativa de superação, sugerindo que, pelo seu exemplo, essas pessoas façam o mesmo, e incentiva principalmente que "se aceitem como são" e sejam elas mesmas, o que é contraditório quando a imposição do "seja você mesmo" funciona como um padrão de como se deve ser.

Parece que essa exposição da intimidade é exercida não tanto como uma forma de autoconhecimento ou autoajuda, uma vez que o fato narrado não coincide temporalmente com o momento de construção da narrativa e, inclusive, segundo Felipe Mastrandéa, já foi superado. Parece ser principalmente com vistas à manutenção de um status de subcelebridade cujo reconhecimento depende da visibilidade. E Felipe Mastrandéa tem consciência de que a confissão geraria essa visibilidade, assim como a vigilância por parte do público. Aliás, era o que almejava ao extimizar seu segredo. Ele conta que se não fosse o HIV, não teria criado o canal e, consequentemente, não seria visto. Além disso, pelos imperativos "dê um joinha" e "se inscreva no canal" proferidos por ele, assim como adotado por vloggers em geral, percebe-se, ainda, o interesse em conseguir likes e seguidores.

No vídeo analisado, Felipe Mastrandéa faz a revelação, sem muitos detalhes ou informações sobre o HIV, discute a respeito da culpabilização dos soropositivos, tenta desvincular o vírus dos imaginários de morte e doença e dá recomendações sobre a importância de realizar o teste para conhecer a sorologia e de iniciar o tratamento em caso de diagnóstico positivo. Apesar desse caráter de conscientização, contraria o discurso médico ao não dar a mesma importância à prevenção.

No final do vídeo 289, Felipe Mastrandéa anuncia que outros detalhes serão expostos em um próximo vídeo - o que faz no vídeo 291 ao relatar como se deu a infecção e a descoberta do diagnóstico - numa estratégia para manter a audiência e os acessos ao canal. Em seguida, Felipe Mastrandéa convida os espectadores para um bate-papo no seu perfil no Moovz $^{11}$, uma rede social direcionada à comunidade de lésbicas, gays, bissexuais, transexuais, travestis e transgêneros (LGBTs), onde promete responder as perguntas dos internautas sobre detalhes não contados no vídeo, o que também é estratégico para atrair as pessoas em outra plataforma. Entretanto, essas questões, veiculadas em seguida no seu canal, referemse principalmente a curiosidades sobre ele, o que atesta o interesse das pessoas pelo comum

\footnotetext{
${ }^{11}$ Disponível em: www.moovz.com/r/felipe.
} 
e corriqueiro. Com isso, Felipe Mastrandéa deixa à margem discussões sobre o HIV que seriam importantes para fornecer informações ao público, o que era o objetivo do vlogger quando ele se propôs a ajudar outras pessoas.

Ao contrário de outros vloggers que também se revelaram soropositivos, como Gabriel Comicholi ${ }^{12}$ e João Geraldo Neto $^{13}$, Felipe Mastrandéa não narra como foi ou está sendo o seu tratamento ou como é o seu dia a dia convivendo com o vírus, distanciando-se do caráter de diário dos demais vloggers, mas, ao tratar de temáticas como sexo, corpo, amor e saúde, aproxima-se dos antigos diários íntimos.

Para captar audiência, Felipe Mastrandéa faz seu relato por meio de discursos que apelam para o sexo e se valem do humor, inclusive com a presença de risadas, construindo, assim, as videografias de si com fragmentos de sua história e direcionamento direto aos espectadores, a quem confere bastante importância. Entretanto, por vezes, com o uso equivocado de alguns termos, reforça estereótipos usados recorrentemente na sociedade para culpar as pessoas com HIV, como aqueles relacionados à promiscuidade e à irresponsabilidade, como percebido no vídeo 291, quando Felipe Mastrandéa diz que se infectou porque "era uma puta que transou bastante sem camisinha" e "não ligava para as consequências". Dessa forma, ao invés de aproveitar a sua plataforma, que possui potencial de reverberação na internet, para tentar romper estes estereótipos, acaba intensificando-os.

\section{Referências bibliográficas}

ALMEIDA, Daniel Mazzaro Vilar de. Performatividades gays: um estudo na perspectiva brasileira e argentina. 2016. Tese (Doutorado em Estudos Linguísticos) - Programa de PósGraduação em Estudos Linguísticos, Universidade Federal de Minas Gerais, Belo Horizonte, 2016.

ALMEIDA, Maria Rita; LABRONICI, Liliana. A trajetória silenciosa de pessoas portadoras do HIV contada pela história oral. Ciência \& Saúde Coletiva, Rio de Janeiro, v. 12, n. 1, p. 263274, jan./mar. 2007.

ARFUCH, Leonor. 0 espaço biográfico: dilemas da subjetividade contemporânea. Rio de Janeiro: EDUERJ, 2010.

BEZERRA, Júlio Carlos. Nós, sujeitos autobiógrafos: uma história de narradores, romancistas e 'cineastas do eu'. Revista Contracampo, Rio de Janeiro, n. 16, p. 199-224, 2007.

BRASIL aumenta diagnóstico e tratamento para o HIV. Portal do Departamento de Vigilância, Prevenção e Controle das IST, do HIV/AIDS e das Hepatites Virais, 04 dez. 2017. Disponível em: <www.aids.gov.br/node/65068>. Acesso em: 5 fev. 2018.

\footnotetext{
${ }^{12}$ Disponível em: www.youtube.com/user/Gabrielcomicholi.

${ }^{13}$ Disponível em: www.youtube.com/user/Nettinhos.
} 
BRITO, Ana Maria de; CASTILHO, Euclides Ayres de; SZWARCWALD, Célia Landmann. AIDS e infecção pelo HIV no Brasil: uma epidemia multifacetada. Revista da Sociedade Brasileira de Medicina Tropical, Uberaba, v. 34, n. 2, p. 207-217, mar./abr. 2001.

BRUNO, Fernanda. Máquinas de ver, modos de ser: vigilância, tecnologia e subjetividade. Porto Alegre: Sulina, 2013.

CERCA de 21 milhões de pessoas vivendo com HIV estão em tratamento, diz novo relatório global do UNAIDS. Portal do UNAIDS Brasil, 20 nov. 2017. Disponível em: < unaids.org.br/2017/11/cerca-de-21-milhoes-de-pessoas-vivendo-com-hiv-estao-emtratamento-diz-novo-relatorio-global-do-unaids>. Acesso em: 5 fev. 2018.

COSTA, Bruno. Videografias de si: registro do novo ethos da contemporaneidade. Cadernos da Escola da Comunicação, Curitiba, v. 1, n. 5, p. 1-15, 2007.

COSTA, Bruno. Práticas autobiográficas contemporâneas: as videografias de si. Revista Digital de Cinema Documentário, Portugal, n. 6, p. 141-157, ago. 2009.

DECLARAÇÃO DOS DIREITOS FUNDAMENTAIS DA PESSOA PORTADORA DO VÍRUS DA AIDS. Encontro Nacional de ONG que Trabalham com AIDS, Porto Alegre, 1989.

DORNELLES, Juliano Paz. 0 fenômeno vlog no YouTube: análise de conteúdo de vloggers brasileiros de sucesso. 2015. Dissertação (Mestrado em Comunicação) - Faculdade de Comunicação Social, Pós-Graduação em Comunicação Social, Pontifícia Universidade Católica do Rio Grande do Sul, Porto Alegre, 2014.

ERBOLATO, Mario. Técnicas de codificação em Jornalismo. São Paulo: Ática, 1991.

FOISIL, Madeleine. A escritura do foro privado. In: CHARTIER, Roger (org.). História da vida privada 3: da Renascença ao Século das Luzes. São Paulo: Companhia das Letras, 2009. p. 321-358.

GOULEMOT, Jean Marie. As práticas literárias ou a privacidade do privado. In: CHARTIER, Roger (org.). História da vida privada 3: da Renascença ao Século das Luzes. São Paulo: Companhia das Letras, 2009. p. 359-396.

HEINICH, Nathalie. De la visibilité: excellence et singularité en régime médiatique. Paris:Gallimard, 2012.

HELAL, Ronaldo. Mídia, construção da derrota e o mito do herói. In: HELAL, Ronaldo; SOARES, Antonio Jorge; LOVISOLO, Hugo. A invenção do país do futebol: mídia, raça e idolatria. Rio de Janeiro: Mauad, 2001. p. 149-162.

HÉNAFF, Nolwenn. Blog: um diário pessoal para existir, ver e ser visto. In: AUBERT, Nicole; HAROCHE, Claudine (org.). Tiranias da visibilidade: o visível e o invisível nas sociedades contemporâneas. São Paulo: Fap-Unifesp, 2016. p. 153-180.

MARCONDES FILHO, Ciro. O capital da notícia: jornalismo como produção social da segunda natureza. São Paulo: Ática, 1986.

MASTRANDÉA, Felipe. Para maiores de 18 anos (289). 2017. (6m26s). Disponível em: $<$ www.youtube.com/watch?v=Q4AunbY9YXQ>. Acesso em: 20 maio 2018. 
MASTRANDÉA, Felipe. Para maiores de 18 anos (291). 2017. (5m44s). Disponível em: $<w w w . y o u t u b e . c o m / w a t c h ? v=q z B N g 3 a m d G k \& t=19 s>$. Acesso em: 20 maio 2018.

MASTRANDÉA, Felipe. Para maiores de 18 anos (292). 2017. (4m17s). Disponível em: <www.youtube.com/watch?v=LEQ9-jol7Fs\&t=74s >. Acesso em: 20 maio 2018.

MISKOLCI, Richard. A gramática do armário: notas sobre segredos e mentiras em relações homoeróticas masculinas mediadas digitalmente. In: PELÚCIO, Larissa et al. (org.). Sexualidade, gênero e mídia: olhares plurais para o cotidiano. Marília: Cultura Acadêmica, 2012a. p. 35-52.

MISKOLCI, Richard. Teoria Queer: um aprendizado pelas diferenças. Belo Horizonte: Autêntica; UFOP, 2012b.

PINHEIRO, Chloé. Homens jovens ou homossexuais ainda são as grandes vítimas do HIV. Saúde Abril, 30 nov. 2018. Disponível em: <saude.abril.com.br/medicina/homens-jovensou-homossexuais-ainda-sao-as-grandes-vitimas-do-hiv>. Acesso em: 10 fev. 2018.

RANUM, Orest. Os refúgios da intimidade. In: CHARTIER, Roger (org.). História da vida privada 3: da Renascença ao Século das Luzes. São Paulo: Companhia das Letras, 2009. p. 211-626.

ROJEK, Chris. Celebridade. Rio de Janeiro: Rocco, 2008.

SEDGWICK, Eve Kosofsky. Epistemologia do armário. Berkeley: University of California Press, 1990.

SENNETT, Richard. 0 declínio do homem público: as tiranias da intimidade. São Paulo: Companhia das Letras, 1988.

SIBILIA, Paula. Os diários íntimos na internet e a crise da interioridade psicológica. In: CONGRESSO DA ASSOCIAÇÃO NACIONAL DOS PROGRAMAS DE PÓS-GRADUAÇÃO EM COMUNICAÇÃO, 12., 2003, Recife. Anais [...]. Recife: UFPE, 2003.

SIBILIA, Paula. O show do eu: a intimidade como espetáculo. Rio de Janeiro: Contraponto, 2016.

TURNER, Graeme. Understanding celebrity. London: SAGE, 2004.

The coming out of the second closet: analysis

of Felipe Mastrandéa's autobiographic

narratives

\begin{abstract}
This paper presents a discussion on the elucidation of themes from the realms of private (SENNETT, 1988) and secret (SEDGWICK, 1990) through the analysis of Felipe Mastrandéa's autobiographic narratives on his YouTube channel, in which the vlogger reveals his seropositivity. From this analysis, we aim to
\end{abstract}


notice how the construction of these videographies of selves (COSTA, 2007; 2009) as well as the coming out of the so called second closet (MISKOLCl, 2012a). To this end, we resourced to bibliographies about contemporary journals on the internet and on HIV. Once this virus, as well as other sex-related issues, is located in the field of secrecy, mostly because of its historically attributed stigma, we approached themes such as public versus private, intimacy exposure, and visibility regimes, supported by the contributions of Arfuch (2010), Bruno (2013), Sibilia (2003; 2016), Goulemot (2009), Ranum (2009), Foisil (2009), among other authors. As main results we perceived that the videographies are marked by an imbrication of public and private. In this specific case, the personal dominion is publicized with strategic function, to acquire visibility and to keep a status of web celebrity. Nevertheless, this revelation is partial, once Felipe Mastrandéa gives more importance to the exposure of the homosexual identity and less to the seropositivity. Moreover, his telling he lives with HIV could be used by him as a positioning against prejudicial and discriminatory speeches. However, the vlogger ends up, on the contrary, reinforcing the stereotypes related to promiscuity and to irresponsibility.

\section{Keywords}

Videographies. YouTube. Felipe Mastrandéa. Closet. HIV.

Recebido em 31/05/2018

Aceito em 06/;10/2018 